\title{
Children's participation and agency in Italian residential care for children: Adult-child interactions at dinnertime
}

\author{
Marzia Saglietti $^{1} \cdot$ Cristina Zucchermaglio $^{2}$ \\ Received: 13 April 2020 / Revised: 30 December 2020 / Accepted: 4 January 2021 / \\ Published online: 7 April 2021 \\ (C) The Author(s) 2021
}

\begin{abstract}
This paper analyzes the impact of adults' interactive moves and strategies on children's participation and agency at dinnertime in two Italian residential care facilities, one of the most widely used alternative care life-context for children and youth coming from vulnerable families. Participants are 14 children and 11 educators living in two residential care facilities in Rome (Italy). Adopting an interactional and multimodal analytic approach, this paper focuses on two dinnertime activities: the routine activity of praying before eating and the very frequent one of talking about rules and transgressions. The comparative analysis of the two facilities shows how, in stable patterns of adult-child interactions recurring across different activities in the same facility, adults' strategies and interactive maneuvers differently impact on children's participation and agency and consequent socialization practices. In the conclusion, we emphasize the relevance and implications of this study for either research in educational sciences and for professionals operating in alternative care and related fields.
\end{abstract}

Keywords Residential care for children · Adult-child interactions · Children's participation and agency $\cdot$ Socialization $\cdot$ Ethnography $\cdot$ Interactional and multimodal analysis

\section{Introduction}

Residential care facilities for children are alternative care settings where out-of-home children recover after having experienced severe hardships, such as parental neglect and/ or physical and psychological abuses, maltreatments, and adverse experiences associated with poverty, multiple out-of-home placements, and general instability (Sellers et al.

Marzia Saglietti

marzia.saglietti@unibo.it

1 Department of Education “G.M. Bertin”, University of Bologna, Bologna, Italy

2 Department of Social and Developmental Psychology, Sapienza University of Rome, Rome, Italy 
2020). Following national laws and regulations, in Italy, residential care for children (RCC) is characterized by an overall rights-based approach (Molinari et al. 2002) with "aspects and interpersonal relationships similar to those of a family" (Ministero del Lavoro e delle Politiche Sociali 2017, p. 6).

Traditionally, RCC has been primarily studied for investigating children's psychosocial and clinical issues connected either to their experiences of abuse and neglect (Rutter 2000; Cicchetti et al. 2003; Rutter et al. 2007) and to the effects of their institutionalization (Bloom 1964; Arieli et al. 2001). However, little is known about adult-child interactions taking place in RCC. Compared with the rich amount of interactional research on socialization practices in family and at school (Ochs and Schiefflin 1984; Orsolini and Pontecorvo 1992; Blum-Kulka and Snow 2002; Rogoff 2003; Pontecorvo and Sterponi 2002)_demonstrating that adult-child interaction is a primary socializing experience - this gap is far more astonishing.

Bridging this gap and drawing on an in-depth ethnographic study of two Italian residential care facilities, in this paper, we present an interactional and multimodal analysis of adult-child interactions occurring in RCC. Particularly, we focus on dinnertime interactions as they are considered one privileged arena for the investigation of socialization practices and a powerful locus for children's participation (see Blum-Kulka 1997; Ochs et al. 1996; Ochs and Shohet 2006). For the purpose of this study, we selected two dinnertime activities: the routine activity of praying before eating and the particularly frequent one of talking about rules and transgressions. Comparing the "same" activities allows us to analyze in detail how specific interactive moves of adults (i.e., educators) contribute to shape either elaborated or restricted global trajectories of participation and agency for children in RCC. In so doing, this study contributes to the alternative care research as well as to other educational fields by showing the many socialization practices that adults - either (foster) parents or professionals working with children (such as teachers, educators, jurists, and social workers) - can rely on to sustain children's development, cultural appraisal and learning.

The present paper is structured as follows: In "Residential care for children: An interactional approach to adult-child interactions," a concise review of the most relevant literature on RCC and dinnertimes as sites of adult-child interaction will be presented. In "Methods," the methodology on which the present study is based on will be described. The results of the analysis are discussed in "Results," followed by "Discussion," which summarizes the main findings and comments on this study's limitations and strengths.

\section{Residential care for children: an interactional approach to adult-child interactions}

As confirmed by the international literature (Swartz 2005; Ward 2006; Grietens 2014), RCC has been primarily studied by means of clinical and/or psycho-social methodologies, focusing on their (individual and institutional) wellbeing. More recent contributions address the

\footnotetext{
${ }^{1}$ The Italian Guidelines for RCC establish that the "family characterization" of RCC is due to: (a) organizational elements (i.e., the reduced number of hosted children); (b) structural elements (i.e., the personalization of spaces); (c) "quality and intensity of relationships between children and professionals" (Ministero del Lavoro e delle Politiche Sociali 2017, p. 6). For an international comparison, see Lee and Barth (2011).
} 
"transformative role" of RCC in the lives of children and young people (Lyons and Schmidt 2014; Whittaker et al. 2016). Still, very few studies describe how RCC is interactively organized and managed (Libby et al. 2005). Notable exceptions are the ethnographic studies (Anglin 2002; Tan 2010; van Es et al. 2019; Smith 2020; on the methodological relevance of using ethnography to study RCC, see Pöso 2004) that focus on the "thousands of unnoticed informal interaction between staff and residents that occur in the daily routines" (Palareti and Berti 2009, p. 1081), such as the construction of an ordinary daily life (Ward 2004), the available literacy practices and timetables (Tan 2010), the challenges of hosting unaccompanied minors (van Es et al. 2019), the violent behaviors of young people (Smith 2020), and the behavioral change of children (Bastianoni et al. 1996). However, these studies fail to account for and describe in detail RCC's interactions and, particularly, adult-child interactions, reinforcing the view of RCC as an under-explored "black box" (Libby et al. 2005; Palareti and Berti 2009).

Filling this gap, this article aims at investigating RCC as sites of adult-child interactions and, more broadly, as sites of cultural socialization (Vygotskij 1929; Greenfield and Bruner 1969; Rogoff et al. 2007) where children can become progressively more competent members of the communities in which they live, through their participation and agency (together with adults and their peers in the cultural practices that characterize them). In this sense, if compared to other and far more studied educational contexts such as families and schools, RCC can be considered a "hybrid" site of socialization: it has different educational aims (i.e., recovering after traumatized experiences), a higher number of non-resident and non-stable adults, it hosts children only temporarily-and with an unstable time horizon. Still, much of the research on socialization practices we can rely on is based on family and school interaction, focusing specifically on the cultural practices of socialization thereby taking place.

\section{Socializing children through adult-child interactions}

Interactional research devoted specific attention to understand the cultural and situated activities and socialization practices taking place in adult-child interactions in family and at school, particularly by relying on interactional and multimodal approaches. Within the Language Socialization Framework (Ochs and Schiefflin 1984; Duranti et al. 2011), and merging ethnographic observation with the in-depth examination of adult-child interactions, a vast array of studies focuses on how children are asked to carry out specific tasks or comply to certain conducts (Craven and Potter 2010; Aronsson and Cekaite 2011; Hepburn and Potter 2011; Goodwin et al. 2012). Several resources are employed to this aim, including: (a) at the verbal level, the use of grammatical forms as requests (instead of commands or threats) and explanations (instead of references to the norm) (see Fasulo et al. 2007; Craven and Potter 2010; Hepburn and Potter 2011); (b) at the metalinguistic level, prosodic intensifications, and vocal modulators of affection (Goodwin and Goodwin 2000; Pauletto and Fatigante 2015); (c) at the multimodal level, the coordination of multiple semiotic resources (see Cekaite 2010; Streeck et al. 2011; Goodwin and Cekaite 2013, 2014; Goodwin 2017). The interactional and multimodal analyses of these choreographies of ordered trajectories of actions show how the establishment of "a framework for mutual orientation" among adults and children (Goodwin et al. 2012) is in itself a target objective of socialization practices, requiring a long sequence of efforts and negotiations from both parties. Interactional and multimodal research devoted 
specific attention to the study of socialization practices taking place in family and, particularly, occurring at dinner.

\section{Adult-child interactions at dinner: children's participation and agency}

With its focus on people "doing family" activities instead of fixed family roles, the ethnomethodological approach to family interactions (Tannen et al. 2007) - together with the Language Socialization approach (Ochs and Schiefflin 1984)-largely contributed to analytically describe adult-child interactions occurring at dinnertime (Blum-Kulka 1993, 1997; Ochs and Taylor 1992; Pontecorvo and Fasulo 2001; Blum-Kulka and Snow 2002) and, particularly, on children's participation and agency.

The term "participation," theoretically dense, is used to analytically describe the strictly social experience of living in the world as members of multiple communities (e.g., family) and therefore as actively involved (with actions, thoughts, and discourses) in practices characterized by the presence of others (see Goodwin and Goodwin 2004). During dinnertimes, family members - children among - differently participate in terms of discursive roles (Ochs and Taylor 1992), presence (Ochs et al. 2010), positioning (Arcidiacono and Pontecorvo 2010), and types of talk (Kendall 2006).

Taking inspiration from Goffman (1981), in their analysis of family narratives, Ochs and Taylor (1992) identify distinctive discursive roles for both children and adults: the applicant (eliciting the narrative); the initial narrator (producing the first prepositions of the narrated story); the problematizer (the one who characterizes the protagonist or the narrator of problematic elements); and the problematized (the participant invested with problematic aspects during the narration) (for a focus on problematization and conflict in family interaction, see Arcidiacono and Pontecorvo 2009). In her ground-breaking analysis of family dinnertime participation framework, Blum-Kulka (1997) distinguishes participants' different footings - i.e., participants' alignment to the discursive activity at hand (Goffman 1981) - and describes that these alignments depend also on the available frames of talk (Kendall 2006).

In line with these studies, the interactional line of research shows that participation appears to be strictly connected to participants' agency (Duranti 2004). The way in which participants - children among - play a role with other people and with the material and sociocultural context depends not only on the contextual clues and constraints but also on their individual (potential) capacity as knowledgeable actors to enact, renew the given context by aligning and disaligning and affiliating and disaffiliating (see Heritage and Raymond 2005; Stivers 2008). In this line, drawing on sociocultural theorizing (Vygotskij 1929; Greenfield and Bruner 1969), children's agency can be defined as an interactional process connected to their initiatives ${ }^{2}$ that "develops in situ and over time. That is, it [children's agency] is a relational achievement which creates opportunities for children not only to copy or repeat the activity, but also to transform it" (Sairanen et al. 2020 , p. 2). Family interaction scholarship devotes specific attention to the investigation of children's agency (Fasulo et al. 2007; Arcidiacono and Pontecorvo 2009) and shows that children can "display a high degree of agency and initiative, contesting, negotiating, and proffering bargains through contrapuntal directives and counter-requests" (Sirota

\footnotetext{
${ }^{2}$ With the term children's initiative, we mean "the relates or unrelated attempt to influence the ongoing interaction" (Sairanen et al. 2020, p. 2; on this issue, see Linell 2009).
} 
2006, p. 509). Children's agency performance appears to be strictly connected to the locally available opportunities that caregivers acknowledge.

In so doing, this dinnertime interactive literature documents the pivotal role of parents' interactional moves and strategies to socialize their children to the values and norms typical of their culture. For example, Arcidiacono and Bova (2011) show the role of ironic comments and the admonition of the parent's authority as an efficacious strategies for conflict management and resolution during dinnertime talk of Italian and Swiss families. Bova and Arcidiacono (2013) have also illustrated a specific invocation-defined as "the authority of feelings"- used by parents in argumentative discussions with children. More recently, Bova (2020) analyzes 30 video-recorded discussions between parents and children during mealtimes around issues that are generated both by parental directives and children's requests. Results suggest how these conflictual interactions have a crucial educational and socializing function for children. Learning to deal with disagreements through solid choreographies of argumentative exchanges and negotiations influences children's competence to actively participate also in "out of home" interactions with peers and adults.

Adopting a similar theoretical and methodological perspective for analyzing dinnertime adult-child interactions in the two residential care facilities, our work aims at exploring the ways in which children (and adults) participate and make the difference in dinnertime interactions in RCC. Particularly, we will examine how specific educators' initiatives and interactional moves contribute to create choreographies of everyday interactions in RCC (Tulbert and Goodwin 2011; Goodwin et al. 2012; Fatigante et al. 2020), allowing (more or less) elaborated trajectories of participation and agency development for children.

\section{Methods}

The study is part of a larger Ph.D ethnographic research project aimed at analyzing the everyday talk and work of three Italian residential care facilities based in Rome (Saglietti 2012, 2019; Zucchermaglio et al. 2013) ${ }^{3}$. The research received approval from the University Ethics Committee, from the local Social Services of the Municipality of Rome (IT) and from the deputy public prosecutor of the local juvenile court. The researcher's access was negotiated with the local Social Services manager as well as with the professionals working in the selected settings (i.e., managers, social educators, psychologists, supervisors, volunteers). During these meetings, the researcher illustrated the aims and methods of the study as well as the practices to ensure confidentiality and anonymity to all involved participants. Professionals and children's tutors signed a written informed consent prior to data collection, according to the Italian Law concerning data protection and privacy.

\footnotetext{
${ }^{3}$ The main goal of the research was investigating RCCs as sites of "family interaction" by comparing three facilities' interactional and organization patterns. The research gathering, conducted by the first author of this paper, took place from October 2007 to May 2008. Three different facilities were involved, each of them hosting no more than 8 children. They were chosen in collaboration with the Municipality of Rome and a local association of residential facilities for their being good representative examples of the main organizational patterns of group care (Lee and Barth 2011) in Italy (i.e., facilities run by religious orders, by non-residentstaff and by a couple of spouses).
} 
For the purpose of the study, we used a mixed-method approach: participant pen-topaper observations of daily activities, shadowing of social educators and managers, audio-recordings of the staff's weekly meetings (from 4 to $10 \mathrm{~h}$ for each facility), video-recordings of dinnertime interactions (around $7 \mathrm{~h}$ for each facility), in-depth ethnographic interviews and informal conversations with professionals (around $3 \mathrm{~h}$ for each facility) were conducted by the first author of this article during the 8-months ethnographic research. Additionally, we video-recorded the meeting with staff members to discuss data interpretation ( $5 \mathrm{~h}$ in total).

\section{Contexts and participants}

For the purpose of this article, we selected two out of the three residential care facilities of the Ph.D study. They have been chosen as to their similarities in terms of: (a) population density of living unit, hosting no more than 8 children at the time of the research; (b) staffing ${ }^{4}$, being organized around resident adults supported by a staff of social educators and (c) age of children, hosting children from 4 to 16 years old.

The first facility - fictionally called "Nuns' Home" - belongs to a Catholic Congregation ${ }^{5}$ based in a building that previously hosted an orphanage. After the 149/2001 Law, the building has been divided into two separate small residential units. Nuns' Home is one of them. Managed by three resident nuns (Nun Paola, Nun Luisa, and Nun Antonella), with one nonresident educator (working on weekday afternoons) and a psychologist (offering in-house psychological support) Nuns' Home hosted 7 children ( 4 boys and 3 girls, from 4 to 13 years old) at the time of the research.

The second setting - "Family Home" - is a family-staffing residential care facility in which a resident family (Chiara and Francisco, with their daughter Daniela, aged 4 at the time of the research) is supported by non-resident staff (4 educators with different levels of seniority), living with children over a 5-day shift ${ }^{6}$. At the time of the research, Family Home hosted 6 children ( 4 boys and 2 girls) from 10 to 16 years old.

\section{Data collection, selection, and analysis}

Dinnertime interactions were video recorded during five consecutive weekdays in both settings. They were then fully transcribed according to the Jeffersonian conventions (Jefferson 2004; see Appendix Table 4), to which symbols were added to annotate multimodal elements of actions co-occurring within and between each speech turn. In transcripts, names of children and adults have been fictionalized and images were altered in order to protect participants' privacy.

For the analysis of the transcripts, we rely on the interactional and multimodal analytical approach that not only focuses on the analysis of action sequences, but also on their environing contexts (thanks to the ethnographic knowledge of the field), and design of turns at talk that

\footnotetext{
${ }^{4}$ Particularly impacting on our choice to involve these two RCCs was their staffing conditions as they both are organized with "live-in family staff that provide a more family-like environment that more closely approximates foster care than programs that rely on staff changes every 8 h" (Lee and Barth 2011, p. 262).

${ }^{5}$ Following last available data (CNDAIA 2019), $21 \%$ of RCC in Italy directly belongs to Roman Catholic Congregations.

${ }^{6}$ During the weekdays, educators operate in 8 hours-shifts (in the mornings, in the afternoons and during nights) that are organized from Monday to Friday. Weekends are instead covered by Francisco and Chiara.
} 


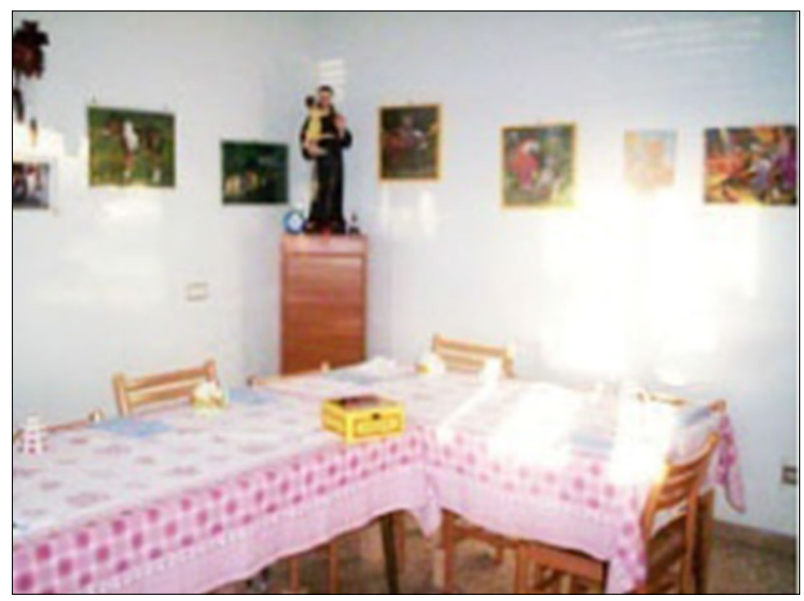

Fig. 1 Nuns' Home's refectory

implement actions (see Fatigante et al. 2020). In application to adult-child interactions (see Bateman and Church 2017), this approach enables the examination of how mutual comprehension and participation is achieved via the orderly and sequentially produced multimodal interaction.

After having examined, within the whole corpus of video-recordings, a subset of group activities, where children differently participate and display their agency within adult-child interactions, we then looked for and analyzed educators' interventions. Subsequently, we joined in collective discussion to identify the educators' strategies contributing to the activity at hand and attempted to find similar routine activity to make a more effective comparison between different facilities. We then adopted a sequentiallybased analysis which followed the temporal and sequential development of the episodes, from the moment in which children's conduct occurred to the moment in which either children complied with the educators' request and/or call for attention and re-orientation

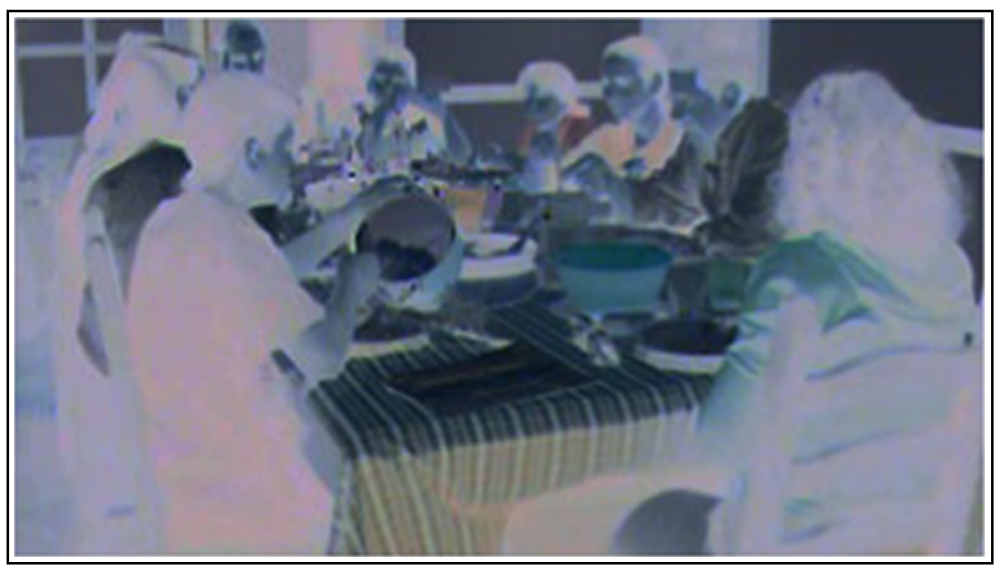

Fig. 2 Family Home's typical dinnertime setting 
to the activity, or the episode moved to an end. We focused on the particular multimodal configurations and choreography (including gestures, posture, spatial positions of the body among the participants, manipulations of objects and material context, as described by Goodwin 2000) constituting the key resources for the educators' (re)direction and (re)orientation of children toward the expected conduct and the main, officially established, participatory rules of the activity.

For the purpose of this article, we then restricted our selection to two different activities: a) praying before eating, and $b$ ) the management of children's behaviour when diverging from the locally expected courses of action and norms, that we briefly describe as the activity of talking about rules and transgressions. The first activity, i.e., praying before eating, constitutes a routine available in both settings, where it signals the shift from other tasks to dinnertime, representing a significant way to socialize children into grace and morality (Capps and Ochs 2002). The second activity, i.e., talking about rules and transgressions, appears to be very frequent in RCC even if it is not predictable. It could include a huge heterogeneity in terms of topics, participation, and timing. Across all transcripts, the authors selected the occurrences of these activities in the two settings, for a total of 10 episodes of praying before eating and 13 occurrences of talking about rules and transgressions. After this first stage of analysis, we joined in collective discussions and data sessions as to conduct an in-depth sequential and multimodal analysis of these episodes, using participation framework and children agency as main analytical tools for comparison. In what follows, we present the analyses of two episodes for each of the selected activities, which can be considered representative examples of the participation and agency of children and of the multiple interactive strategies and moves used by adults.

\section{Results}

In the above-mentioned settings, dinnertimes were differently organized. At Nuns' Home, dinners were served in what they call "the refectory" (see Fig. 1) at 7:20 pm. Only children and nuns can participate here. Meals are prepared in advance by the cooker of the Congregation in a separate part of the building and are sent in the apartment through an internal elevator.

Rather, at Family Home, meals are consumed on a big wood table next to the kitchen and they are shared by both children and adults (staffed educators and resident adults) around eight o'clock in the evening. Meals have been previously prepared either by the staff and by Chiara, the resident "mum", both frequently involving children too (see Fig. 2).

\section{Praying before eating}

As in many families (Capps and Ochs 2002; Ochs and Shohet 2006), praying represents a discursive, semiotic, and kinesic activity taking place each evening before eating. The following excerpt occurs at Nuns' Home. Here, children have just finished taking their showers and they stand in front of their chairs dressed in their pajamas. Nun Paola has already taken her dinner in a separate room (see Box $1^{7}$ ).

\footnotetext{
${ }^{7}$ Excerpts are presented in two lines: in the original Italian and in an idiomatic translation in American English that follows line by line the original material.
} 


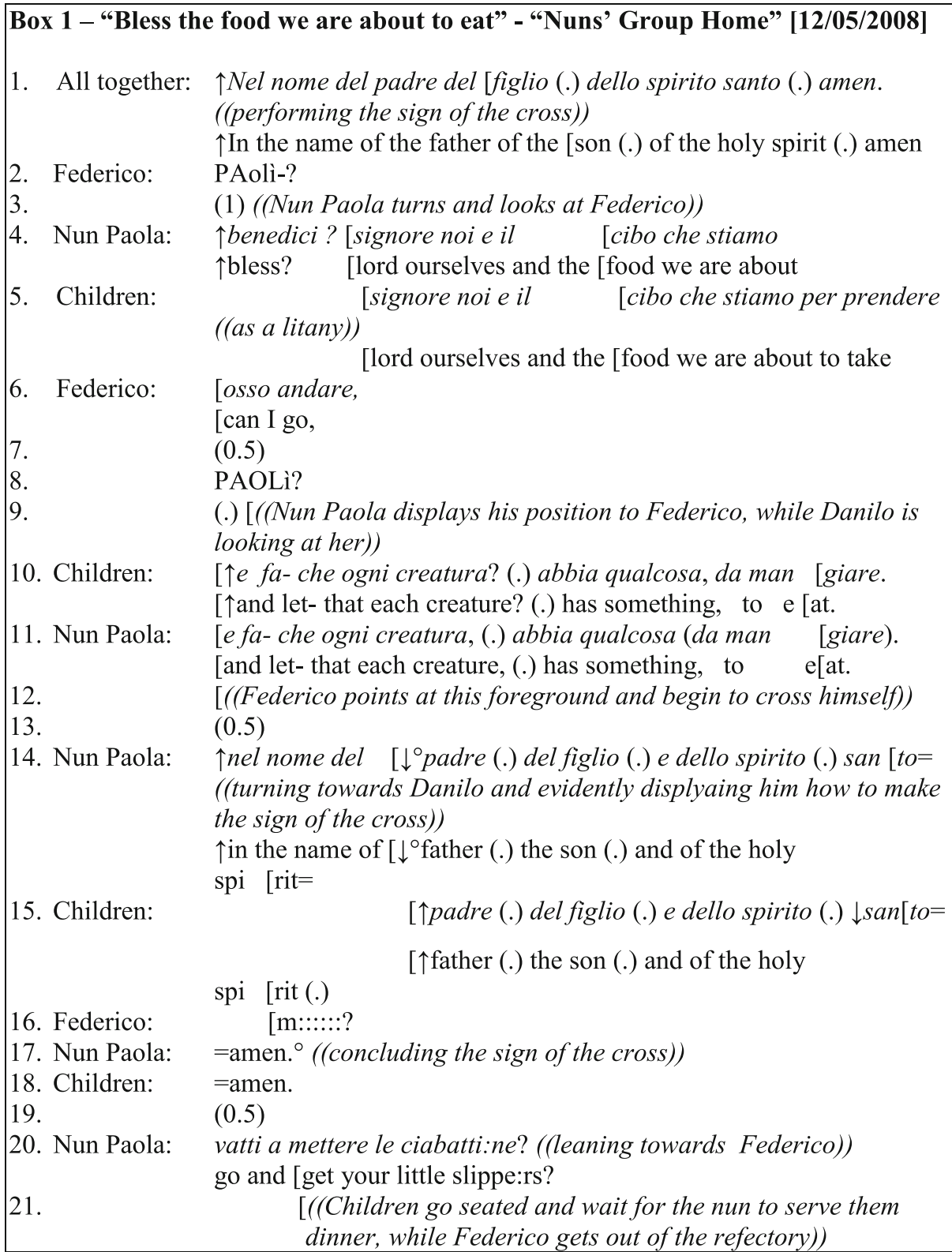

As Box 1 shows, the prayer's topic and text of the invocation are fixed, the prosody and related multimodal activities are already established and monitored, and children's (as well as adult's) participation is closely restricted. Children are the animators (Goffman 1981) of this prayer: they have to memorize a text that is not theirs (nor-as far as we know-it is literally belonging to the traditional Catholic liturgy) and perform it appropriately through their 
multimodal conduct. Conversely, Nun Paola is the leading performer and (potential) author of the text.

However, from line 2 on, Federico - a 5-year-old boy with cognitive problems and language difficulties - starts problematizing the prayer format by showing his disalignment to the interaction at hand. After an attempt (see lines 2 and 3), in lines $6-8$, he formulates his request by calling the nun with her nickname (“Can I go, Paoli?") and by expressing his intention to go out. Nun Paola does not verbally reply to the boy's request: rather, without stopping to perform her role as leading guide of the collective prayer, she exploits many nonverbal maneuvers of shepherding (Cekaite 2010)_looking at him, as in line 3, showing him her hands clasped together, line 9-to align Federico to the activity at hand. From his side, the boy tries to accelerate the conclusion by starting to cross himself before the exact time (line 12), and by re-proposing his request (line 16) before the final "amen" (line 17). In these terms, Federico appears to be particularly agentic as he acts as problematizer of the format. Aligning and disaligning with the prayer-format to make his request, his participation reveals that, even in such a formatdriven and normatively supervised activity, there is a minimal space for contribution and challenge. Also Danilo, 4 years old, disaligns from the activity of praying ${ }^{8}$ as the recipient of many interventions of Nun Paola (intensively look at him, displaying him how to make the sign of the cross, line 14). In both cases, Nun Paola physically embodies the multimodal and modelled experience of praying (straight posture, head bowed, hands joined together in front of her chest, loud and liturgic tone of voice), shepherding not only the two little boys - and each of them for (apparently) different reasons ${ }^{9}$ - but also the entire group of children as her designed recipient. Interestingly, this does not interrupt the main activity-i.e. the collective prayer-that appears to be highly coordinated, bodily incorporated, and normatively undertaken with little possibility for children to contribute at its innovation and development.

Differently from Excerpt 1, at Family Home praying is a negotiated activity that is led in turn either by adults or children. In the following excerpt, eight children and three adultsChiara, the resident mum; Diletta, an educator; and Dino, a young volunteer-are about to eat. Tommaso - a 10-year-old boy - proposes himself as the leading guide of the ritual dinnertime prayer (see Box 2).

With loudly calling his designed recipient in lines 1 and 3, Tommaso not only exhibits his request to allocate his right to be the author of the prayer, but at the same time confirms Chiara as the controller of the activity. From line 5 to line 10, Chiara ratifies the boy's right to lead the activity (line 5), sits and exhales (lines 5, 6, and 8), signaling the shift from the activity of serving the meal to the one of collectively praying. When she finally declares "here we are" (line 10), Tommaso hesitates and asks for a private space to investigate if his intentions of praying can be considered adequate. The interruption of the main activity and consequent opening of a sequence of a private conversation within the public sphere is not contested by other participants, who rather wait for them with an attentive prayerful attitude (see lines 13-26). It is

\footnotetext{
${ }^{8}$ Danilo was hosted at "Nuns' Home" just few weeks before the beginning of video recordings. During an ethnographic interview, Nun Paola referred that the boy was born and grew up in a therapeutic community in which there was no habitude to pray.

${ }^{9}$ In the case of Federico, Nun Paola is postponing the boy's request by asking him to adhere to the prayer format (already known by the boy), while in the case of Danilo she is displaying him how to pray as he is described as not having any previous knowledge on the matter.
} 


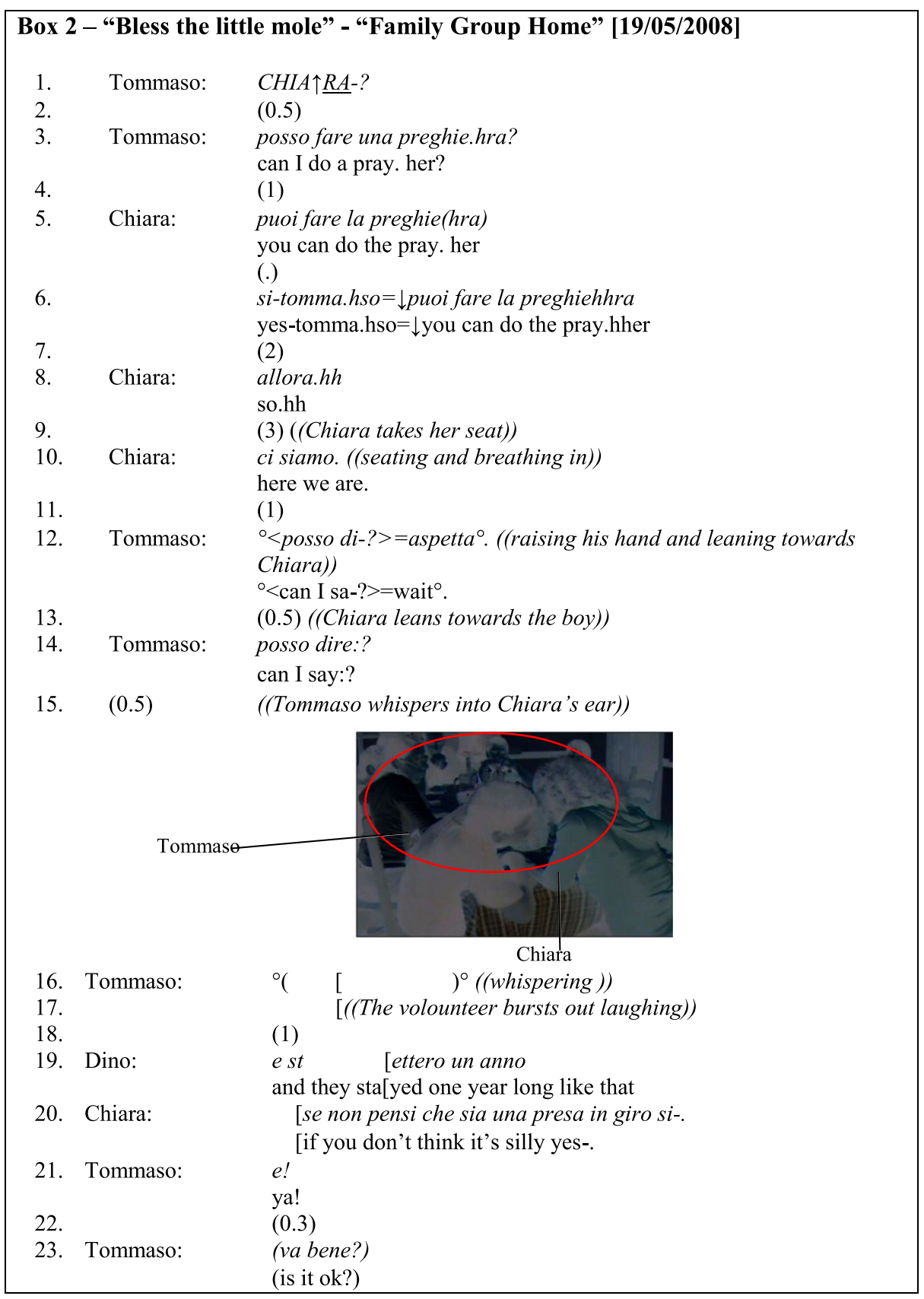

only Dino, the volunteer, an occasional participant of Family Home, that breaks up this attitude, laughs (line 17) and ironically signals, without being acknowledged, the changing frame of the private-into-public conversation (line 19). From his part, Tommaso continues to talk into Chiara's ears, but his intervention is inaudible. Nor 


\begin{tabular}{|c|c|c|}
\hline 24. & & (1) \\
\hline 25 . & Chiara: & $\begin{array}{l}\text { ¿va bene. } \\
\text { 'it's ok }{ }^{\circ} \text {. }\end{array}$ \\
\hline 26. & Tommaso: & $\begin{array}{l}>\text { nel nome del }<\text { padre figlio spirito santo (.) amen. ((performing the } \\
\text { sign of the cross)) }\end{array}$ \\
\hline 27. & & $\begin{array}{l}>\text { in the name of }<\text { the father son holy spirit }(.) \text { amen } \\
(0.5)\end{array}$ \\
\hline 28. & Tommaso: & $\begin{array}{l}\text { signore (mio) }>\text { benedici questo cibo }<\text { e ti ringraziamo per }>\text { que }<\text { st } \\
\text { giornata } \\
\text { (my) lord }>\text { bless this food }<\text { and we thank you for }>\text { th }<\text { is day }\end{array}$ \\
\hline 29. & & (.) \\
\hline 30 . & & $\begin{array}{l}\text { benedica la talpina } \\
\text { bless the little mole }\end{array}$ \\
\hline 31. & & (.) \\
\hline 32. & & $>$ che è morta oggi< \\
\hline 33. & & $>$ that is dead today $<$ \\
\hline 34. & & $(0.5)$ \\
\hline 35 . & & $<$ amen $>$. \\
\hline 36. & & $(0.3)$ \\
\hline $\begin{array}{l}37 . \\
38 .\end{array}$ & Chiara: & $\begin{array}{l}\text { AMEN! } \\
(0.5)\end{array}$ \\
\hline 39. & Tommaso: & $\begin{array}{l}\left.\left.{ }^{\circ} \text { padre del figlio spirito santo }{ }^{\circ} \text { ((performing the sign of the cross }\right)\right) \\
{ }^{\circ} \text { father of the son holy spirit }{ }^{\circ}\end{array}$ \\
\hline $\begin{array}{l}41 . \\
42 .\end{array}$ & All: & $\begin{array}{l}\text { nel nome del padre del figlio dello spirito santo } \\
\text { in the name of the father the son and the holy spirit } \\
\text { ((Everyone starts to eat)) }\end{array}$ \\
\hline
\end{tabular}

it is Chiara's assessment - “If you don't think it's silly, yes" (line 20) - that opens up a moral qualification over the prayer topic and consequently renders it publicly available the object of their talk, i.e., the adequacy of Tommaso's prayer intentions.

In so doing, she confirms her role of gatekeeper, problematizer and principal of the prayer. From his side, Tommaso is called to make an autonomous decision: whether he finds his intention consistent with the qualification of Chiara (what he is going to pray for should not be silly), he can go on, otherwise he needs to change his mind. In this dilemma, Tommaso is called to acknowledge not only his agency as (potential) author of the prayer, but he is also held accountable for what he is going to propose to pray for. In receiving Chiara's assessment, Tommaso hesitates (line 21) and again asks her a confirmation (line 22). It is only when she grants him her positive assessment with a repetition (line 25) that he signals the opening of the prayer format. From that moment on, he leads the prayer using verbal and nonverbal maneuvers to request the blessing of God over the food (28), the day (29) and over the little mole that has been found dead in the garden the previous afternoon (30-32). In doing so, Tommaso-author and animator of this activity - not only exploits his agency, but also qualifies this activity as a site for recounting an intimate culture and collective experience. From her side, Chiara makes the difference by regulating the space of action for Tommaso and by allowing him to analyze and autonomously evaluate the adequacy of his "creative" contribution to the activity at hand. As a result, the prayer appears to be highly negotiated, with possibilities to be interrupted, reformulated, and interactively managed. 
Table 1 "Nuns' Home" and "Family Home" adults' and children's participation and agency as observed in the discursive excerpts

\begin{tabular}{|c|c|c|}
\hline & Nuns' Home & Family Home \\
\hline \multicolumn{3}{|c|}{ Participation framework } \\
\hline $\begin{array}{l}\text { Children's } \\
\text { participa- } \\
\text { tion }\end{array}$ & $\begin{array}{l}\text {-Animators: children memorize a text and } \\
\text { perform it appropriately through their verbal } \\
\text { and non-verbal conduct (as in Box 1) } \\
\text {-Problematizers (as Federico in Box 1): little } \\
\text { children can disalign with the activity at } \\
\text { hand by proposing one own's requests and } \\
\text { problematizations } \\
\text {-Children participate as: (a) problematized as } \\
\text { the designed recipients of adults' requests } \\
\text { and directives and (b) ratified audience who } \\
\text { needs to listen the interrogatory and the rule } \\
\text { declamation; (c) co-narrators, co-- } \\
\text { problematizers, and spies with aligning and } \\
\text { affiliating to adult's narratives modes (as in } \\
\text { Box 3) }\end{array}$ & $\begin{array}{l}\text {-Authors and animators of the prayers (see Box } \\
\text { 2) } \\
\text {-Children are considered held accountable of } \\
\text { their (prayers') intentions and formulations } \\
\text { (as in Box 2) } \\
\text {-Children participate as: (a) problematized for } \\
\text { their (potential) misconduct and global tra- } \\
\text { jectories (as in Box 4); (b) ratified audience } \\
\text { that can intervene as problematizer as well; } \\
\text { (c) unratified audience; (d) mediators; (e) } \\
\text { ironical commentators of the situation at } \\
\text { hand (as in Box 4) }\end{array}$ \\
\hline $\begin{array}{l}\text { Adults' } \\
\text { participa- } \\
\text { tion }\end{array}$ & $\begin{array}{l}\text {-Authors of the text of the prayer (as in Box 1) } \\
\text {-Leading performers of the activity's } \\
\text { multimodal conducts (with attention to little } \\
\text { children, as in Box 1) } \\
\text {-Controllers of children's conduct (as in Box 1) } \\
\text { - Narrators of the occurred transgressions (as in } \\
\text { Box 3) } \\
\text {-Interrogators: posing numerous questions } \\
\text { (most of them, rhetorical ones, as in Box 3) } \\
\text {-Evaluators of children's conducts, with relying } \\
\text { also on IRE sequences (see Box 3) } \\
\text {-Problematizers who allocate individual } \\
\text { responsibilities } \\
\text { "Voices of the law": establishing what the rule } \\
\text { is, what the risks are, who has to be } \\
\text { considered accountable for and finally } \\
\text { looking for agreements over the rule at stake } \\
\text { (as in Box 3) }\end{array}$ & $\begin{array}{l}\text {-Multimodal gatekeepers of the activity at } \\
\text { hand (see Boxes } 2 \text { and 4) } \\
\text {-Principal (as Chiara does in Box 2) } \\
\text { Problematizers as they supervise the moral } \\
\text { suitability of children's interventions (as in } \\
\text { Box 2) } \\
\text {-Problematizers of childrens' conducts, ratified } \\
\text { audience, unratified audience, mediators (as } \\
\text { in Boxes } 2 \text { and 4) }\end{array}$ \\
\hline \multicolumn{3}{|c|}{ Agency displaying patterns } \\
\hline $\begin{array}{l}\text { Children's } \\
\text { agency }\end{array}$ & $\begin{array}{l}\text { - Particularly restricted (as in Boxes } 1 \text { and } 3 \text { ) } \\
\text { - Children are problematized and held } \\
\text { accountable for what they do and think (as in } \\
\text { Box 3); if considered guilt, they are obliged } \\
\text { to reply to the questions addressed to them } \\
\text { as designated recipients of adults' questions } \\
\text {-Transgressors can resist the alignment by } \\
\text { using an un-cooperative silence or other } \\
\text { forms of conversational resistance (as in } \\
\text { Box 3) } \\
\text {-Children's disalignment and disaffiliation is } \\
\text { interactively sanctioned (as in Box 3) }\end{array}$ & $\begin{array}{l}\text {-As adults, children are problematized and held } \\
\text { accountable for what they do and think (as } \\
\text { in Boxes } 2 \text { and } 4 \text { ) } \\
\text { - Children can refuse, resist, meta-communicate, } \\
\text { align and disalign, using irony to critically } \\
\text { affiliate with the affective stance of the } \\
\text { conversation }\end{array}$ \\
\hline $\begin{array}{l}\text { Adults' } \\
\text { agency }\end{array}$ & $\begin{array}{l}\text {-Particularly marked } \\
\text {-Adults' narratives are privileged } \\
\text { - They can pose multiple questions without } \\
\text { being contested } \\
\text {-Their meaning-making activity is } \\
\text { unnegotiated, taken for granted and } \\
\text { unproblematized (as in Box 3) }\end{array}$ & $\begin{array}{l}\text {-Adults consider themselves to be held } \\
\text { accountable and justify their interactional } \\
\text { behaviors } \\
\text {-Adults' meaning-making activity is negotiated } \\
\text { with children and other adults } \\
\text {-Adults' actions can be contested and } \\
\text { negotiated (as in Box 4) }\end{array}$ \\
\hline
\end{tabular}


Table 2 "Nuns' Home" and "Family Home" adult-child interactions

\begin{tabular}{|c|c|c|}
\hline & Nuns' Home & Family Home \\
\hline $\begin{array}{l}\text { Adult-child } \\
\text { interac- } \\
\text { tions }\end{array}$ & $\begin{array}{l}\text {-Highly normative } \\
\text {-Highly coordinated, normatively undertaken } \\
\text { activities with little possibility for children to } \\
\text { contribute (other than with resistance or } \\
\text { un-negotiated compliance) } \\
\text { •Children's contributions are interpreted as } \\
\text { transgressions from the general normative } \\
\text { rule and treated as such } \\
\text {-Adults' contributions are treated as they don't } \\
\text { need justifications and accounts } \\
\text { •Centered on adults' interpretations, panopticon } \\
\text { and global control }\end{array}$ & $\begin{array}{l}\text {-Children and adults can negotiate the meaning } \\
\text { of their activities and co-construct different } \\
\text { options and behaviors } \\
\text {-Adults' contributions are treated as children's } \\
\text { and need to be justified and held accountable } \\
\text { "Open complex negotiation sequences" } \\
\text { (Fatigante et al. 2021) supported by a wide } \\
\text { array of multimodal resources and centered } \\
\text { on mutual interpretations and negotiation }\end{array}$ \\
\hline
\end{tabular}

\section{Talking about rules and transgressions}

Drawing on a sociocultural perspective (Zittoun and Perret-Clermont 2009), norms and rules - part of any educational setting as transformative milieu - represent very rich arenas of socialization as they are acquired "not only through routines and directives but also through an explicit interpretation and evaluation of everyday behavior" (Arcidiacono and Pontecorvo 2009 , p. 111). In this sense, the activity of managing children's behavior when diverging from the locally expected courses of actions, i.e., talking about rules and transgressions, represents an important discursive arena to make sense out of the individual's behavior as well as out of the collective experience taking place in RCC, as in other educational settings.

In the following excerpts, we analyze two representative examples of adults and children talking about two interpreted-as-problematic behaviors: in the first case, they discuss about a transgressive behavior that occurred in the afternoon (see Box 3), while in the second case a (potential) problematic behavior is occurring real time during dinner (see Box 4). Both episodes represent special sites for investigating how rules are negotiated, what participation framework is locally built up and maintained and what agency resources children (and adults) rely on.

In the first episode, occurring at Nun's Home, two children are called to retrospectively explain the reasons why in the afternoon they went to the garden without being allowed to (see Box 3).

Table 3 Educators' interactional moves and strategies fostering children's participation and agency in RCCs

-Asking children to auto-evaluate their talk and intentions;

-Making open questions, instead of commands and threats (see Fasulo et al. 2007);

-Leaving space for meaning negotiation and argumentation;

-Leaving space for children's refusal and alternative meaning-making;

-Sustaining meta-communication sequences;

-Using accounts and explanations to make everyone's actions intelligible (see Craven and Potter 2010; Hepburn and Potter 2011);

-Suspending the use of qualification directed to children to avoid labelling children;

-Using irony, affective terms, and intimate references (see Arcidiacono and Bova 2011);

-Recurring to the "authority of feelings" (Bova and Arcidiacono 2013) to convey an affective stance over argumentative strategies;

-Managing private-into-public sequence (and protecting them) to negotiate with children over the discursive meta-communication about the activity at hand. 


\section{Box 3 - "What did you do that it must not be done?" - "Nuns' Home" - 14/05/2008}

1. Nun Paola: e che cosa avete fatto che non bisognava fa:re? so what you have done that you don't have to do:?

2. (1)

3. Nun Paola: che cosa hai fatto? ((looking at Danilo)) what have you done?

4. $(0.5)$

5. (Federico): (um).

6. Nun Paola: $\quad \underline{\text { eh}}$ ? dimmi. ((taking the bread box away from Danilo)) what? tell me.

7. (2) ((Federico pat Nun Paola's arm))

8. Martina: io che non lo so (.) $\downarrow$ dai. to me that i don't know it (.) $\downarrow$ come on.

9. Nun Paola: che non si $\uparrow$ face:va:? (looking towards Danilo)) that you don't $\uparrow$ have to: do:?

$10 . \quad(0.7)$

11. Martina: $>$ che avete fatto $<$ vo $[i$

$>$ what did you do $<$ yo[u

12. Nun Paola: [che cosa è che non si face:va:? (looking towards Federico)) [what it is that it hasn't to be do:ne:

13. Federico: giù-((pointing his hand towards the table)) down-

14. $(0.8)$

15. Nun Paola: bra:vissimo. (.) [个andare? exce:llent. (.) [个going?

16. Martina: $[>\uparrow$ sono andati giù $<$ senza dirt $\quad[$ elo? $[>\uparrow$ they went downstairs $<$ without say[ing it to you?

Paola nods))

$[((N) n$

17.

(0.5)

18. Nun Paola: $\uparrow$ anda: [re? giù.

19. Martina: go: [ing? downstairs:. [e chi $>$ ha aperto la porta $<$. [and who $>$ opened the door $<$.

20. Nun Paola: lui ha aperto (.) ché è più [grande ((pointing at Federico)) he opened (.) because he's [older

21. Matteo: [sì lui è capace a aprirla! ((pointing at Federico)) [yes he is able to open it!

22. Nun Paola: lui ha aperto la porta he opened the door

Box 3 represents a very dense "rewind narrative" (Zucchermaglio and Fasulo 2008) focused on a pressing list of questions (lines 1-39) that looks like a police interrogatory of a detective story (Ochs and Capps 2001). Here, in a non-negotiated way, Nun Paola tries to tell the story from her point of view with recurring to many discursive actions: 


\begin{tabular}{|c|c|c|}
\hline \multicolumn{2}{|l|}{23.} & \multirow{3}{*}{$\begin{array}{l}\text { [ma chi è stato a dire an-andiamo giù? } \\
\text { [but who's the one saying le- let's go downstairs? } \\
\text { [bru:tto cattivone ((towards Federico)) } \\
\text { [na:sty boy }\end{array}$} \\
\hline \multirow[t]{2}{*}{24.} & Martina: & \\
\hline & & \\
\hline 26 & Nun Paola: & $\begin{array}{l}\text { chi l'ha detto andiamo giù (.) tu? ((pointing to Danilo)) } \\
\text { who said it let's go downstairs (.) you? }\end{array}$ \\
\hline \multirow{2}{*}{$\begin{array}{ll}27 . \\
28 .\end{array}$} & & (2) \\
\hline & Nun Paola: & $\begin{array}{l}\text { tu hai detto andiamo giù } \\
\text { you said let's go downstairs }\end{array}$ \\
\hline $\begin{array}{l}29 . \\
30 .\end{array}$ & Martina: & $\begin{array}{l}\text { (1.5) } \\
\text { si-lui lo dice spesso [andiamo giù ( ) }\end{array}$ \\
\hline 31. & Nun Paola: & 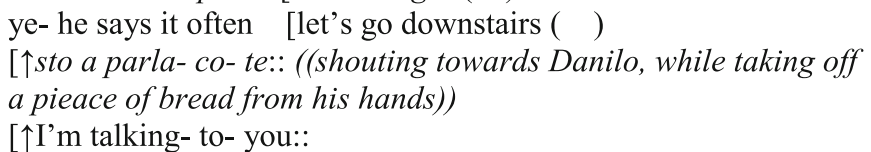 \\
\hline \multirow{2}{*}{$\begin{array}{l}32 . \\
33 .\end{array}$} & Martina: & ( ) \\
\hline & Nun Paola: & tu l'hai detto andiamo [giù:? \\
\hline & & you said it let's go $\quad \frac{[\text { downstai:rs? }}{[(\text { (Danilo nods }))}$ \\
\hline \multirow{2}{*}{$\begin{array}{l}34 . \\
35 \\
36\end{array}$} & & $(0.5)(($ Federico nods repeatedly $))$ \\
\hline & Nun Paola: & $\begin{array}{l}\text { e lui ha aperto la porta:. } \\
\text { and he opened the doo:r. }\end{array}$ \\
\hline 37. & & (1.5) ((Nun Paola points to Federico)) \\
\hline \multirow{2}{*}{$\begin{array}{l}38 . \\
39\end{array}$} & Matteo: & $(\quad[)$ \\
\hline & Nun Paola: & $\begin{array}{l}{[\uparrow \text { non si fa? ((signaling no with her hands)) }} \\
{[\uparrow \text { it hasn't to be done? }}\end{array}$ \\
\hline 40 & & (1) \\
\hline 41. & Nun Paola: & $\begin{array}{l}\text { pericoloso } \\
\text { dangerous } \\
(0.5)\end{array}$ \\
\hline 43. & Nun Paola: & $\begin{array}{l}\text { sì } o \quad[\text { no. } \\
\text { yes or }[\text { no. }\end{array}$ \\
\hline 44 & Martina: & $\begin{array}{l}\text { [figurati se non ce stava suor antonella: sotto. } \\
\text { [imagine if there wasn't nun antonella: downstairs. }\end{array}$ \\
\hline 45. & Nun Paola: & $\begin{array}{l}\uparrow \text { se non c'era suor } \uparrow \text { antonella:, che facevate? ((banging the } \\
\text { table)) } \\
\uparrow \text { if there wasn’t nun } \uparrow \text { antonella:, what have you done? } \\
\text { (1) }\end{array}$ \\
\hline 47. & Martina: & $\begin{array}{l}>\text { stavano da soli }< \\
>\text { they were by themselves }<\end{array}$ \\
\hline \multirow[t]{2}{*}{48.} & Nun Paola: & $\begin{array}{l}\uparrow e h ? \\
\uparrow \text { what? }\end{array}$ \\
\hline & & (1) \\
\hline
\end{tabular}

she reconstructs the chain of the events; she problematizes what happened; she renders the two transgressors accountable for what they have done, depicting and allocating their individual responsibilities in each phase of the transgression (deciding to go downstairs, proposing one another, opening the door, going downstairs, playing in 


\begin{tabular}{|c|c|c|}
\hline 50. & Nun Paola: & $\begin{array}{l}\text { da soli (.) } \uparrow \text { io? (.) se vi mando } \uparrow \text { io? (.) che vi gua:rdo dalla } \\
\text { finestra ((imitating the gesture of looking)) } \\
\text { by yourself. (.) } \uparrow \text { me? (.) if it’s } \uparrow \text { me? sending you (.) and loo:king } \\
\text { at you from the window }\end{array}$ \\
\hline 51. & & $(1)$ \\
\hline 52. & Nun Paola: & $\begin{array}{l}\text { allora io vi guardo vedo e poi vi dici } \\
\text { then i look you i see you and then i tell you }\end{array}$ \\
\hline 53. & & $(0.5)$ \\
\hline 54. & Nun Paola: & $\begin{array}{l}\text { oh! state qui sotto sotto ((pointing)) } \\
\text { hey! stay here close close } \\
(0.5)\end{array}$ \\
\hline 56. & Nun Paola: & $\begin{array}{l}\text { cosi vi vedo be:ne: }(1.5) \text { eh. } \\
\text { so that i can see you: we:ll (1.5) eh. } \\
(\ldots .)\end{array}$ \\
\hline 89. & Nun Paola: & $\begin{array}{l}\text { e quindi? (.) si va giù da so:li? } \\
\text { so what? (.) you can go downstairs by yourse:lves? }\end{array}$ \\
\hline 90. & & $(0.5)(($ Federico nods, then shakes his head $))$ \\
\hline 91. & Nun Paola: & $\begin{array}{l}\text { non si va giù da soli (.) vero? } \\
\text { you don't have to go downstairs by yourselves (.) right? }\end{array}$ \\
\hline 92. & & (1.5)((Federico points at Nun Paola $))$ \\
\hline 93. & Nun Paola: & $\begin{array}{l}\text { bisogna dirlo a me. ((pointing at herself)) } \\
\text { you have to tell me. }\end{array}$ \\
\hline 94. & & $(0.5)$ \\
\hline 95. & Nun Paola: & $\begin{array}{l}\uparrow \text { pa:oli:? (0.5) possiamo andare giù:? } \\
\uparrow \text { pa:olì:? }(0.5) \text { can we go downstai:rs? }\end{array}$ \\
\hline 96. & & (1) ((Federico nods $))$ \\
\hline 97. & Nun Paola: & $\begin{array}{l}\text { e io dico si.. (0.5) vi guardo }(0.5) \uparrow n o: ?(0.5) \text { aspetta:te }(0.8) \\
\text { vero? } \\
\text { and i say yes.. (0.5) i see you (0.5) } \uparrow \text { no:? (0.5) wai.t (0.8) right? } \\
\text { (3) ((Federico nods)) }\end{array}$ \\
\hline
\end{tabular}

the garden ${ }^{10}$ ); she voices the rule and finally looks for agreement. The excerpt could be divided into several parts. From line 1 to line 37, Nun Paola establishes a preparatory phase in which she exploits numerous close questions and repetitions to retrace the transgression, globally conveying a sense of growing tension. However, the questions posed to children appear to be rhetorical: as demonstrated by the overall narrative, Nun Paola already knows how things evolved over time. From line 12 to line 15, she recurs to a typical school discursive device-the IRE sequence (initial state, response,

\footnotetext{
${ }^{10}$ These actions appear to be differently treated during the excerpt. The discussion on the action of door opening occupies three turns of talk (lines 20-22), while more conversational floor is occupied by revolving around the act of having planned the transgression (lines 23,26, 28 and 33). In this light, it appears as though Nun Paola is giving more agentic power and responsibility to the act—and related agent-of having planned to go in the garden without asking her. In so doing, Danilo is pictured as the most responsible agent of this transgression. This can be connected also to other situational reasons. First, as Federico-differently from Danilo-displays cognitive and language problems, he is probably perceived as the second-in-command and potential victim of the other one. Secondly, the moral evaluation of the act of planning could have its roots on the Catholic tradition, where bad intentions are particularly sanctioned. Thirdly, in a Roman-centered juridical approach — as it is the case of the Italian laws and regulations - premeditated acts are more severely punished than non-premeditated ones.
} 
evaluation, see Wells 1993) - posing a question (line 12), and evaluating (line 15) Federico's answer (line 13). This case underlines the paradoxical effect of praising him for the answer, even if he is the transgressor of the event.

After a global reconstruction of the event with the active support of Martina (line 30) and the more peripherical one of Matteo (line 21), it is finally in line 39 that Nun Paola qualifies the transgression in form of a minimal account ("dangerous"). This passage paves the way for what comes next: when Martina cries "Imagine if there wasn't Nun Antonella downstairs" (line 44) she exploits a fiction-i.e., the creation of an imaginary scenes over the past situation (Zucchermaglio and Fasulo 2008) - to convey an alarmed affective stance projection over the past transgression (line 45). In doing so, she potentially opens a space for retrospective meaningmaking with the two children as designated recipients. Unfortunately, as shown by Martina, this change of frame is hindered. After a pause (line 46), the girl occupies this interactive slot and replies with recalling an evidence ("they were by themselves," line 47) that implicitly downgrades the risk of the episode and disaffiliates with the alarmed tone of the nun. This disaffiliation is immediately amended with an open class repair initiator (Drew 1997) ("what?," line 48) addressing Martina's whole previous turn as problematic. By reaffirming the alarmed affective stance, with the following sequence Nun Paola re-establishes a simplified code with elementary expressions, repetitions and reported discourses (lines 50-56) as if it was a baby talk. Then, after emotionally recalling her experience of not seeing the children in the apartment (not transcribed), from line 89 to line 98, she once again re-establishes the "how-to-do" rule and finally asks for agreement, that is conveyed by Federico, repeatedly nodding (lines 88, 90, 96).

Overall, this episode conveys all the preoccupation from the adult's part, who not only speaks "the voice of the law" and normatively re-establishes the rule but also discursively ventriloquizes a panopticon (Foucault 1975; Ochs and Capps 2001) agent that has to see everything in order to "socialize" children. In this episode, little negotiated space for meaningmaking or alternative moral horizons is allowed, nor any space is given to the exploration of the reasons behind children's conducts.

In so doing, Nun Paola's agency appears to be particularly marked, while children participation and agency appears to be very restricted. The group of children is treated as the ratified audience that needs to be publicly exposed to the rule. Particularly, Federico and Danilo are the designed recipients of many questions, repetitions, and requests for agreements. However, the two boys display different roles and related agency. Whether Federico replies with his nonverbal conduct confirming his involvement in the transgression and the final agreement over the rule declamation, Danilo replies to the pressing question-list only once (line 34). His perpetrated silence-being constructed as the guiltiest one (see note 10, above) - appears to be particularly critical: is it either an act of resistance and/or the impossibility of saying anything? In this participation framework, children in fact can perform a very restricted array of actions: they can/have to listen to what is being said; they can/have to reply when questioned (and, in doing so, they can receive an evaluation); they can/have to comply with Nun Paola's comments (as Martina frequently does, co-problematizing ${ }^{11}$ what has been

\footnotetext{
${ }^{11}$ Martina's discursive role as co-problematizer and co-investigator is particularly interesting. During the narrative, she first encourages the elicitation and then proposes the children to be the addressed recipient of their contributions (lines 8 and 10) to facilitate their intervention. Secondly, she contributes to create a moral horizon in which the boys' actions can assumed transgressive tones (line 16). Thirdly, she poses herself as another interlocutor of the interrogatory (lines 20,32), with using many discursive devices that grant her the position as co-problematizer: she makes assessments with negative qualifier ("nasty boy", line 24), she completes the nun's turns (line 47) and refers to the usual behavior of children (line 30).
} 
said, see lines $8,10,16,19,24,44,47$ ) and they can/have to "do the spy" (as Martina-in line 30 - and Matteo - in line 21-do). In the same vein, disaffiliative and/or disaligning contributions (on the distinction between disalingment and disaffiliation, see Stivers 2008) appear to be interactively sanctioned, as it happens when Danilo does not reply (lines 27, 29, 31) and when Martina downgrades the alarmed tones of the adult (line 47). Overall, in this restricted participatory framework - justified by an alarmed perspective from the nun's part—little space is devoted to rule negotiation, nor there's room for the exploration of the reasons behind children's transgression and for the agency displaying from the children's part (with the notable exception of Danilo's refusal to answer).

Differently from Nun's Home, the following excerpt relates to a problematic episode occurred during dinner. It concerns a tension between food preference over fruit and nutritional regimes (on the Italian family approach to fruit in the socialization of taste, see Ochs et al. 1996). The quarrel regards Chiara, the mum, and Marta, a 12-year-old girl with constipation problems at the time of the video recordings, who is said to eat kiwis but does not want to. The interaction occurs in overlapping with other ones, and, particularly with Daniela (the 4-yearold daughter of the couple) that is jumping and running in the kitchen, shouting, and performing loud comments (see Box 4).

From line 6 on, Chiara proposes Marta to take a kiwi-a good source of fiber-to comply to the girl's nutritional regime connected to her constipation problems. In doing so, she exploits the illocutionary force of questions (lines 6, 14), tag questions (as in line 9), repetitions (line 14,16), and directives (line 16) to encourage (line 18) and beg (line 18) the girl. It is particularly her use of accounts (lines 9, 20, 23, 25, and 35) that shows an implicit underlining aspect of her socialization theory: adults need to justify their actions to be accountable ("I'm doing this for your own good," line 35). Differently from excerpt 3, this episode displays many affective verbal expressions (as in line 35) and items, as nicknames (line 6), sarcastic allusions (lines 23-25), ironic comments (lines 32, $34,36,38$ ), and multimodal "affective" activities (see the silent activity of lending fruit to Marta by Manuela in line 21, their frequent smiling, as in lines 26, 32, 38, and gazing, either to convey a sense of annoyance, as in line 15 or to establish a common ground, as in lines 8 and 12). The overall participation of the little child, Daniela, with her playful expressions (see lines 7, 10, 13,33), contributes to coloring the episode with lively affective tones.

The overall participation framework revolves around Chiara, the problematizer, and Marta, the problematized, with their audience as ratified listeners of the conversation. Still, something problematic occurs within the audience. When firstly a social educator and secondly a boy ask for the reasons of the conflict - the first one using a request for clarification based on an individual evaluation of the girl ("why? what's wrong with her?," line 27) and the second one trying to understand if eating kiwis is a new generalized rule ("why? now we have to compulsory eat kiwis?," line 28) — Chiara does not grant them the epistemic right and authority to know what's wrong. With her intervention in line 29 ("it's something between Marta and myself'), she qualifies that piece of interaction as private, designating them as temporal nonratified recipients. On the contrary, Chiara - the interactive manager of the conversationratifies other verbal and nonverbal maneuvers, as for instance, when Manuela lends Marta a kiwi (line 21), when Silvano ironically comments and encourages the girl to eat either fruit or vegetables (lines 34,36 ), acting as if he was a mediator.

After two rejections (lines 11 and 19) and many nonverbal expressions of refusal (lines 8 , 12, 15), Marta finally affiliates (line 26) by meta-communicating with Chiara ("you cannot 


\section{Excerpt 4: "I'm doing this for your own good" - "Family Group Home" [20/05/2008]}

1. Tommaso: p-ss:ate

2.

can you p-a:ss

3.

(0.5)

[un kiwi?

[one kiwi?

4. Daniela

[AAAH!

5.

(1)

6. Chiara:

un kiwi mar [ti::? (1) un kiwi?

one kiwi mar[ti::? (1) one kiwi?

7. Daniela:

8. (2.5) ((Chiara stares at Marta))

[uaia:! (1) uu:? (0.5) upppalà::!

9. Chiara: tu non [hai mangiato le carote, vero?

10. Daniela: you didn't [eat carrots, right?

10. Daniela:

11. Marta: [sì-sì (.) BU:!A:! shouting and jumping))

[yes yes (.) BU:! A:! [U:!

12.

(0.5) ((Chiara and Marta continue to stare at each other. Manuela, the social educator, with Roberto and Tommaso look at Marta))

13. Daniela: MA! [MA A A A? [mangi un kiwi:? [do you eat one kiwi:?

15.

(1) ((Marta looks annoyed))

16. Chiara: mangi la $\uparrow$ mela e mangi anche $\downarrow$ un kiwi. you eat the $\uparrow$ apple and you eat also $\downarrow$ one kiwi.

17. (1) ((Manuela, the social educator, place the fruit box next to herself and takes a kiwi))

18. Chiara: dai (.) ti prego $\quad[\because: !$

19. Marta: come on (.) I beg you[::!

20. Chiara: $\left[{ }^{\circ}\right.$ e no: $\left[: ?^{\circ}\right.$ [ ${ }^{\circ}$ so no: $\left[: ?^{\circ}\right.$ pass[a:re::: [e::h! se no guarda ci tocca

21.

22.

23. Chiara: [e::h! look, otherwise we have to pa:::[ss [((Manuela lends a kiwi to Marta))

24. a via::: to the:::

25 . (0.5) $<$ chimica $>$. $<$ chimical way $>$.

26. (2) ((Marta looks down and smiles))

threaten me this way," smiling, line 32) and smiling back at Silvano's ironical comment (line 38). In what follows (not transcribed), she will finally eat fruit.

Marta's agency is particularly revealing of the kind of communicative resources and practice available for children's participation in this residential facility: she resists, meta- 


\begin{tabular}{|c|c|}
\hline 27. Ed Manuela: & {$\left[^{\circ}\right.$ perché? che le manca $?^{\circ}$} \\
\hline 28. Ivo: & $\begin{array}{l}{\left[{ }^{\circ} \text { why? what's wrong with her } ?^{\circ}\right.} \\
\text { [个perché? }(.) \text { mò se mangia per forza }[(\text { i kiwi)? } \\
\text { [ why? (.) now we have to eat compulsory [(kiwis)? }\end{array}$ \\
\hline 29. Chiara: & $\begin{array}{l}{\left[\uparrow e^{\prime} \text { ' una cosa fra me e marta. }\right.} \\
\text { [^it's something between marta and myself. }\end{array}$ \\
\hline 30. Marta: & $\begin{array}{l}{ }^{\circ} \text { non mi puoi fa- }{ }^{\circ} \\
{ }^{\circ} \text { you cannot do th- }{ }^{\circ}\end{array}$ \\
\hline 31. & (.) \\
\hline 32. & $\begin{array}{l}\text { non mi puoi minacciare in questo modo ((smiling)) } \\
\text { you cannot threaten me this way }\end{array}$ \\
\hline 33. Daniela: & ${ }^{\circ}$ fiù::: [fiù::::० ((jumping through the kitchen)) \\
\hline 34. Silvano: & $\begin{array}{l}{[\text { devi mangià }[\text { le carote }=} \\
\text { ya must eat } \quad[\text { carrots }=\end{array}$ \\
\hline 35. Chiara: & $\begin{array}{l}{[\uparrow l \text { lo faccio per il tuo be:ne:! }} \\
{[\uparrow \text { I'm doing this for your own go::od! }}\end{array}$ \\
\hline 36. Silvano: & $\begin{array}{l}=\text { che sennò diventi cieca! } \\
=\text { otherwise you get blind! }\end{array}$ \\
\hline 37. & $(0.5)$ \\
\hline 38. Marta: & $\begin{array}{l}\text { e.:.:.:.:.? ((laughting and pretending to be blind)) } \\
\text { wha::::::::t? }\end{array}$ \\
\hline 39. & ((Manuela and Chiara laught)) \\
\hline
\end{tabular}

communicates over the situation, aligns and disaligns, always affiliating herself to the affective stance of the situation proposed by Chiara and reinforced by Silvano. In so doing, all participants co-contribute to create an "open complex negotiation sequences" (Fatigante et al. 2020), supported by a wide array of verbal and multimodal strategies, in which the sense of agency and accountability of both adults and children - and their mutual meaningmaking of rules - can be called in play. In this light, this episode constitutes an open "thinking space" (Perret-Clermont 2004) in which the children's agency of opposing, takeoff taking position, exploring, and negotiating the rules is at stake.

\section{Children's (and adults') agency and participation}

To better resume the comprehensive results of our study, Table 1 displays both adults' and children's agency and participation involved in the four excerpts above analyzed.

Table 1 shows that the locally available options and trajectories of participation and agency for children (and adults) are vastly different in the two facilities. At Nuns' Home, children's participation and agency are constantly designed to follow standardized formats (as in Box 1), in which little space is given to children's authorship, negotiation, and meaning-making exploration (see Box 3). The socialization practices thereby available appears to be adultcentered, top-down (from one to many) and based on an intense validation of the (visual and multimodal) control of children, probably with the intent of protecting them from an "outside world", that is perceived as highly risky and harmful (see 3). By using a socializing restricted code (Bernstein 1971) — reproducing a "traditional" teacher/fronted teacher/controlled classroom interaction with repeated questions, requests for agreements, and IRE sequences (see Box 3) - children are socialized to listen to adults' own voice, and to follow it. This asset is revealed also by older children's behavior, monitoring little children as co-problematizers and 
"spies". As ethnographic studies in RCC have demonstrated, "power in an institution is regulated not only through figures in authority but also among those who come under authority" (Tan 2010, p. 41).

Conversely, at Family Home the above-analyzed excerpts show that children can have authorship (see Box 1 and Box 4), are held accountable (as in Box 1), are granted to say no (see Box 4), and are considered able to autonomously auto-evaluate what they say (see Box 1), even in quarrels and negotiations (as in Box 4). Adults open and guide collective spaces for negotiation, meta-communication sequences (see Box 4), and distributed meaning-making activities (see Box 1). The socialization practices thereby available appears to be based on an elaborated code (Bernstein 1971) and on interactive frames that are composed of overlapping sequences (as in Box 4), of different rounds (as in Box 1), and several accounts (as in Box 4). Particularly, the account sequences sustain a broader co-construction and negotiation of rules, justify an understanding of consequences of actions and allow children's autonomy (of thoughts and actions) within the interactional space regulated by adults (and, particularly, by Chiara, the resident spouse of the couple).

\section{Discussion}

As we have displayed, in this paper, the residential care facilities under investigation vastly vary in terms of adult-child interactions (see Table 2).

What is making this marked difference in terms of adult-child interactions? What are adults' detailed interactional and multimodal moves that can foster the development of solid symbolic and semiotic resources with children in RCC?

In line with relevant research literature, our results empirically display that educators' initiatives and interactional strategies that contribute to shape elaborated trajectories and choreographies of participation and agency development for children are as follows: (a) asking children to auto-evaluate what their talk (and intentions) are, reinforcing their accountability as social actors (as in Box 2); (b) making open questions (as in Box 2) instead of commands and threaten (as in Box 3) (see Fasulo et al. 2007); (c) leaving space for meaning-making negotiation and argumentation (as in Box 2 and Box 4); (d) leaving space for children's refusal (as in Box 4) and alternative meaning-making (as in Box 2 and Box 4); (e) sustaining meta-communication sequences (as in Box 4) to foster interaction negotiation and "the capacity of communicating about communication" (Ruesch and Bateson 1951, p. 209); (f) using accounts and explanations to make adults' and children's actions intelligible (as in Box 4) (see Craven and Potter 2010; Hepburn and Potter 2011); (g) suspending the use of qualification directed to children (as in Box 4) to avoid labelling children (as in Box 3); (h) using irony, affective terms, and references to deal with disagreement and negotiation (as in Box 4) (see Arcidiacono and Bova 2011) and globally contributing to the intimate culture of the home; (i) recurring to the "authority of feelings" (Bova and Arcidiacono 2013) to convey an affective stance over argumentative strategies (as in Box 4); (j) managing private-intopublic sequence (and protecting them) to negotiate with children over the discursive metacommunication about activity at hand (as in Box 2 and Box 4). Table 3 illustrates the main findings of this study in terms of adults' strategies fostering children's participation and agency.

These moves appear to be by all means "educational investments" on an active, reflective, and competent cultural socialization of children, that goes well beyond the activities of both 
praying and talking about rules and trasgressions, i.e., a socialization in which children can experiment themselves and meaningfully participate as "thinking beings in thinking spaces" (Perret-Clermont 2004). We can then claim that these appear to be "open complex negotiation sequences" (Fatigante et al. 2020) supported by a wide array of multimodal resources and centered on mutual interpretations and negotiation.

Our results corroborate the research on adult-child interactions in other educational contexts (as school and family) and contribute to widening the knowledge on adult-child interactions and on cultural socialization paths in the important, but until now underexplored, context of RCC. As in school and in family, the interactive moves and strategies of adults can be considered crucial resources for developing (more or less) elaborated, active and creative contexts of children's participation.

In so doing, we have shown that we can "see" the theoretical stance "behind" the design and enactment of everyday interactive activities (see Zittoun and Perret-Clermont 2009) in RCC. By comparing two settings and two dinnertime activities, we have revealed the expectations of conduct and implicit relationship and meaning making concerning authority, legitimacy, competences, interactional rights and duties taking place in RCC. These evidences do not only well resonate with the literature on RCC but also they constitute a unique contribution with respect to the broader adult-child interaction research, in which it is recognized that adults and children do not interact on the basis of a specific "biological designated choreography" (Stern 1977) as every group and socialization context "orchestrates the ways in which children participate in particular situations, and this, in turn, affects the forms, the function, and the content of children's utterances" (Ochs and Schiefflin 1984, p. 311).

\section{Conclusion}

The ethnographic and interactional analytical approach adopted in this study - together with the comparison of two interactional dinnertime activities and facilities - has enabled us to illustrate how RCC can be systematically studied in its everyday talk, opening a reflection on both future research paths and on suggestions for professionals. Despite its limitations ${ }^{12}$, this methodological choice gives access to available socialization practices and reveals, as in other sites of adult-child interactions (Sarangi 2006), the impact of the possibilities given to children. Particularly, in this paper we have shown that children's cultural socialization in RCC highly depends on trajectories of participation and agency development that are allowed, sustained, and fostered by educators' initiatives and interactional strategies (as in Table 3, above).

Future research is then needed to open more deeply the "black box" (Libby et al. 2005; Palareti and Berti 2009) of everyday interactions in residential care and, more broadly, in alternative care. Given the delicacy of children's life trajectories living there, it is crucial to

\footnotetext{
${ }^{12}$ As most interactional and multimodal studies, our findings are limited to the contexts under scrutiny and therefore they cannot be generalized. However, they constitute an example of how participation and agency is negotiated through two discursive activities taking place in ordinary adult-child dinnertime talk. We are also aware that the analysis of interaction occurring at dinner-although based on an ethnography-provides a restricted portrayal of the many socialization practices taking place in $\mathrm{RCC}$, as it does not focus on the other formal and informal adult-child encounters regarding out-of-home children (and their families) such as, for instance: formal meetings (individual interviews, psychotherapy encounters, evaluation meetings) and informal talk with peers, educators and parents.
} 
investigate how adults' strategies and socialization practices contribute to the development of solid symbolic and semiotic resources to face the multiple transitions of their actual and future lives (Zittoun 2006). Even more than their peers, children in alternative care need meaningful socializing paths and rich interactional contexts.

For the professional development of those acting in the field (educators, social workers, psychologists, as well as volunteers), our results can help disseminate activities of observation, video recording and (self)reflection, shared analysis of their daily working practices and interactive strategies for fostering children's participation and agency. Accepting that one's work practices becomes "public" ("observable" and "scrutinized" by other professionals) requires courage and energy on the part of professionals and volunteers, but it has the advantage of making them become actors and authors of their professional development and of the general improvement of the educational quality and richness of the alternative care contexts and services for out-of-home children - residential care within them-in which they work and in which children are living and growing.

\section{Appendix 1}

Table 4. Transcription conventions (Jefferson 2004)

\begin{tabular}{|c|c|}
\hline$(1.5)$ & Pause (in seconds and tenths of seconds) \\
\hline (.) & Micro-pause (shorter than $0.2 \mathrm{~s}$ ) \\
\hline$\uparrow$ & Sudden rise in pitch \\
\hline$\downarrow$ & Sudden drop in pitch \\
\hline . & Descending intonation \\
\hline$?$ & Ascending intonation (not necessarily interrogative) \\
\hline , & Suspended intonation \\
\hline- & Abrupt interruption of talk \\
\hline$=$ & Latching with previous utterance \\
\hline${ }^{\circ}$ text $^{\circ}$ & Quiet volume \\
\hline${ }^{\circ}$ text $^{\circ \circ}$ & Very quiet volume \\
\hline text & Emphasis \\
\hline$\overline{>\operatorname{text}<}<$ & Faster pace of speech \\
\hline$<$ text $>$ & Slower pace of speech \\
\hline[ & Start of overlapping talk \\
\hline$(($ text $))$ & Description of nonverbal activity \\
\hline (text) & Unclear or dubious words \\
\hline ( ) & Unintelligible \\
\hline$:::$ & Elongation of a sound \\
\hline
\end{tabular}

Acknowledgements We would like to thank the EJPE's Editor in Chief, Prof. Baucal, and two anonymous reviewers for their insightful comments and remarks that greatly improved our manuscript. We are also immensely grateful to all children and adults involved in the research project.

Funding Open access funding provided by Alma Mater Studiorum - Università di Bologna within the CRUICARE Agreement.

Open Access This article is licensed under a Creative Commons Attribution 4.0 International License, which permits use, sharing, adaptation, distribution and reproduction in any medium or format, as long as you give appropriate credit to the original author(s) and the source, provide a link to the Creative Commons licence, and 
indicate if changes were made. The images or other third party material in this article are included in the article's Creative Commons licence, unless indicated otherwise in a credit line to the material. If material is not included in the article's Creative Commons licence and your intended use is not permitted by statutory regulation or exceeds the permitted use, you will need to obtain permission directly from the copyright holder. To view a copy of this licence, visit http://creativecommons.org/licenses/by/4.0/.

\section{References}

Anglin, J. P. (2002). Pain, normality, and the struggle for congruence: Reinterpreting residential care for children and youth. Binghamton, NY: Haworth Press.

Arcidiacono, F., \& Bova, A. (2011). Argumentative strategies for conflict management and resolution in Italian and Swiss families. Procedia Social and Behavioral Sciences, 30, 1385-1389. https://doi.org/10.1016/j. sbspro.2011.10.269.

Arcidiacono, F., \& Pontecorvo, C. (2009). Cultural practices in Italian family conversations: Verbal conflict between parents and preadolescents. European Journal of Psychology of Education, 24(1), 97-117. https:// doi.org/10.1007/BF03173477.

Arcidiacono, F., \& Pontecorvo, C. (2010). The discursive construction of the fathers' positioning within family participation frameworks. European Journal of Psychology of Education, 25(4), 449-472. https://doi.org/10. 1007/s10212-010-0024-7.

Arieli, M., Beker, J., \& Kashti, Y. (2001). Residential group care as a socializing environment: toward a broader perspective. Child \& Youth Care Forum, 30(6), 403-414. https://doi.org/10.1023/A:1015321302983.

Aronsson, K., \& Cekaite, A. (2011). Activity contracts and directives in everyday family politics. Discourse \& Society, 22(2), 137-154. https://doi.org/10.1177/0957926510392124.

Bastianoni, P., Scappini, E., \& Emiliani, F. (1996). Children in residential care: How to evaluate behavioural change. European Journal of Psychology of Education, 11(4), 459-471. https://doi.org/10.1007/ BF03173284.

Bateman, A., \& Church, A. (2017). Children's Knowledge-in-Interaction. Singapore: Springer.

Bernstein, B. (1971). Class, codes and control: Volume 1 - Theoretical studies towards a sociology of language. London, UK: Routledge.

Bloom, B. (1964). Stability and change in human characteristics. New York, NY: Wiley.

Blum-Kulka, S. (1993). "You gotta know how to tell a story": telling, tales, and tellers in American and Israeli narrative events at dinner. Language in Society, 22(3), 361-402.

Blum-Kulka, S. (1997). Dinner-talk: patterns of sociability and socialization in family discourse. Mahwah, NJ: Lawrence Erlbaum.

Blum-Kulka, S., \& Snow, C. (2002). Talking to adults. The contribution of multiparty to language acquisition. Mahwah, NJ: Lawrence Erlbaum.

Bova, A. (2020). A qualitative investigation of the issues leading parents and children aged 3-7 years to argumentative discussions during mealtimes. In A. M. Columbus (Ed.), Advances in Psychology Research (Vol. 139, pp. 67-96). Hauppauge, NY: Nova Science Publishers.

Bova, A., \& Arcidiacono, F. (2013). Invoking the authority of feelings as a strategic maneuver in family mealtime conversations. Journal of Community \& Applied Social Psychology, 23(3), 206-224. https://doi. org/10.1002/casp.2113.

Capps, L., \& Ochs, E. (2002). Cultivating prayer. In C. E. Ford, B. A. Fox, \& S. A. Thompson (Eds.), The language of turn and sequence (pp. 39-55). Oxford, UK: Oxford University Press.

Cekaite, A. (2010). Shepherding the child: Embodied directive sequences in parent-child interactions. Text and Talk, 30(1), 1-25. https://doi.org/10.1515/TEXT.2010.001.

Centro Nazionale di Documentazione e Analisi per l'Infanzia e l'Adolescenza (CNDAIA). (2019). Bambini e ragazzi in accoglienza in Italia. Esiti dell'indagine campionaria sull'affidamento familiare e $i$ servizi residenziali [Children and young people in out-of-home care in Italy. Outcomes from the survey on foster care and residential care]. Firenze, IT: Istituto degli Innocenti.

Cicchetti, D., Rogosh, F. A., Maughan, A., Toth, S. L., \& Bruce, J. (2003). False belief understanding in maltreated children. Development and Psychopathology, 15(4), 1067-1091. https://doi.org/10.1017/ S0954579403000440.

Craven, A., \& Potter, J. (2010). Directives: Entitlement and contingency in action. Discourse Studies, 12(4), 419442. https://doi.org/10.1177/1461445610370126.

Drew, P. (1997). 'Open' class repair initiators in response to sequential sources of troubles in conversation. Journal of Pragmatics, 28(1), 69-101. https://doi.org/10.1016/S0378-2166(97)89759-7. 
Duranti, A. (2004). Agency in language. In A. Duranti (Ed.), A Companion to Linguistic Anthropology (pp. 451473). Oxford, UK: Basil Balckwell.

Duranti, A., Ochs, E., \& Schiefflin, B. (2011). The Handbook of Language Socialization. Malden, MA: WileyBlackwell.

Fasulo, A., Loyd, H., \& Padiglione, V. (2007). Children's socialization into cleaning practices: A cross-cultural perspective. Discourse and Society, 18(1), 11-33. https://doi.org/10.1177/0957926507069454.

Fatigante, M., Antici, L., Zucchermaglio, C., Fantasia, V., \& Alby, F. (2021). Orchestrating children's action: An in-depth multimodal analysis of child-educator interactions in one Italian early childhood education setting, European Journal of Psychology of Education. (in press)

Foucault, M. (1975). Surveiller et punir. Naissance de la prison [Discipline \& Punish: The Birth of the Prison]. Paris, FR: Gallimard.

Goffman, E. (1981). Forms of talk. Philadelphia, PE: University of Pennsylvania Press.

Goodwin, C. (2000). Action and embodiment within situated human interaction. Journal of Pragmatics, 32(10), 1489-1522. https://doi.org/10.1016/S0378-2166(99)00096-X.

Goodwin, M. H. (2017). Haptic sociality: The embodied interactive construction of intimacy through touch. In C. Meyer, J. Streeck, \& J. Scott Jordan (Eds.), Intercorporeality Emerging Socialities in Interaction (pp. 73102). Oxford, UK: Oxford University Press.

Goodwin, M. H., \& Cekaite, A. (2013). Calibration in directive/response sequences in family interaction. Journal of Pragmatics, 46(1), 122-138. https://doi.org/10.1016/j.pragma.2012.07.008.

Goodwin, M. H., \& Cekaite, A. (2014). Orchestrating directive trajectories in communicative projects in family interaction. In P. Drew \& E. Couper-Kuhlen (Eds.), Requesting in Social Interaction (pp. 195-241). Amsterdam/Philadelphia: John Benjamins.

Goodwin, C., \& Goodwin, M. H. (2000). Emotion within situated activity. In N. Budwig, I. C. Uzgiris, \& J. V. Wertsch (Eds.), Communication: An arena of development (pp. 33-54). Mahwah, NJ: Lawrence Erlbaum.

Goodwin, C., \& Goodwin, M. H. (2004). Participation. In A. Duranti (Ed.), A companion to linguistic anthropology (pp. 222-244). Oxford, UK: Blackwell.

Goodwin, M. H., Cekaite, A., Goodwin, C., \& Tulbert, E. (2012). Emotion as stance. In A. Peräkylä \& M.-L. Sorjonen (Eds.), Emotion in Interaction (pp. 16-41). New York, NJ: Oxford University Press.

Greenfield, P. M., \& Bruner, J. S. (1969). Culture and cognitive growth. In D. A. Goslin (Ed.), Handbook of Socialization Theory and Research (pp. 633-660). Chicago, IL: Rand McNally.

Grietens, H. (2014). A European perspective on the context and content for social pedagogy in therapeutic residential care. In J. W. Whittaker, J. F. Del Valle, \& L. Holmes (Eds.), Therapeutic residential care with children and youth: Developing evidence-based international practice (pp. 288-301). London \& Philadelphia: Jessica Kingsley Publishers.

Hepburn, A., \& Potter, J. (2011). Threats: Power, family mealtimes, and social influence. British Journal of Social Psychology, 50(1), 99-120. https://doi.org/10.1348/014466610X500791.

Heritage, J., \& Raymond, G. (2005). The terms of agreement: Indexing epistemic authority and subordination in talk-in-interaction. Social Psychology Quarterly, 68(1), 15-38. https://doi.org/10.1177/ 019027250506800103.

Jefferson, G. (2004). Glossary of transcript symbols with an introduction. In G. H. Lerner (Ed.), Conversation Analysis: Studies from the first generation (pp. 13-31). Amsterdam/Philadelphia: John Benjamins.

Kendall, S. (2006). 'Honey, I'm home!': framing in family dinnertimes homecomings. Text \& Talk, 26(4/5), 411441. https://doi.org/10.1515/TEXT.2006.017.

Lee, B. L., \& Barth, R. P. (2011). Defining group care programs: An index of reporting standards. Child Youth Care Forum, 40(4), 253-266. https://doi.org/10.1007/s10566-011-9143-9.

Libby, A. M., Coen, A. S., Price, D. A., Silverman, K., \& Orton, H. D. (2005). Inside the Black Box: what constitutes a day in a residential treatment centre? International Journal of Social Welfare, 14(3), 176-183. https://doi.org/10.1111/j.1468-2397.2005.00357.x.

Linell, P. (2009). Rethinking language, mind, and world dialogically: Interactional and contextual theories of human sense-making. Greenwich, CT: Information Age Publishing.

Lyons, J. S., \& Schmidt, L. (2014). Outcomes management in residential treatment: The CANS approach. In J. W. Whittaker, J. F. Del Valle, \& L. Holmes (Eds.), Therapeutic residential care with children and youth: Developing evidence-based international practice (pp. 316-329). London and Philadelphia: Jessica Kingsley Publishers.

Ministero del Lavoro e delle Politiche Sociali. (2017). Linee di indirizzo per l'accoglienza nei Servizi residenziali per minorenni [National Guidelines on Residential Care for Children]. https://www.lavoro.gov.it/temi-epriorita/infanzia-e-adolescenza/focus-on/minorenni-fuori-famiglia/Documents/Linee-guida-accoglienzaminorenni.pdf Accessed 26 March 2020

Molinari, L., Melotti, G., \& Emiliani, F. (2002). Children's rights in educational relationships. European Journal of Psychology of Education, 17(2), 139-155. https://doi.org/10.1007/BF03173255. 
Ochs, E., \& Capps, L. (2001). Living narrative: Creating lives in everyday storytelling. Cambridge, MA: Harvard University Press.

Ochs, E., \& Schiefflin, B. (1984). Language acquisition and socialization: Three developmental stories. In R. Shweder \& R. LeVine (Eds.), Culture theory: mind, self, and emotion (pp. 276-320). Cambridge, MA: Cambridge University Press.

Ochs, E., \& Shohet, M. (2006). The cultural structuring of mealtime socialization. New Directions for Child and Adolescent Development, 111, 35-49. https://doi.org/10.1002/cad.153.

Ochs, E., \& Taylor, C. (1992). Family narrative as political activity. Discourse \& Society, 3(3), 301-340. https:// doi.org/10.1177/0957926592003003003.

Ochs, E., Pontecorvo, C., \& Fasulo, A. (1996). Socializing taste. Ethnos, 61(1-2), 7-46. https://doi.org/10.1080/ 00141844.1996 .9981526$.

Ochs, E., Shohet, M., Campos, B., \& Beck, M. (2010). Coming together at dinner. A study on working families. In K. Christensen \& B. Schneider (Eds.), Workplace flexibility: Realigning 20th-century jobs for a 21stcentury workforce (pp. 57-70). Ithaca, NY: ILR Press.

Orsolini, M., \& Pontecorvo, C. (1992). Children's talk in classroom discussions. Cognition and Instruction, 9(2), 113-136. https://doi.org/10.1207/s1532690xci0902 2.

Palareti, L., \& Berti, C. (2009). Differential ecological perspectives for evaluating residential care outcomes: Which window for the black box? Children and Youth Services Review, 31(10). Volume, 31(10), 10801085. https://doi.org/10.1016/j.childyouth.2009.07.011.

Pauletto, F., \& Fatigante, M. (2015). 'Dai, da' na mano!' Tra il dire e il chiedere: l'uso del segnale discorsivo dai in conversazioni in famiglia. Rivista di Psicolinguistica Applicata, 25(1), 89-103. https://doi.org/10.1400/ 232660.

Perret-Clermont, A. N. (2004). Thinking spaces of the young. In A. N. Perret-Clermont, C. Pontecorvo, L. B. Resnick, T. Zittoun, \& B. Burge (Eds.), Joining society. Social interaction and learning in adolescence and youth (pp. 3-10). Cambridge, MA: Cambridge University Press.

Pontecorvo, C., \& Fasulo, A. (2001). Mutual apprentices: The making of parenthood and childhood in family dinner conversations. Human Development, 44(6), 342-363. https://doi.org/10.1159/000046155.

Pontecorvo, C., \& Sterponi, L. (2002). Learning to argue and reason through discourse in educational settings. In G. Wells \& G. Claxton (Eds.), Learning for Life in the 21th Century (pp. 127-140). Oxford, UK: Blackwell.

Pöso, T. (2004). The rights and wrongs of ethnographic research in a youth residential setting. In H. G. Eriksson \& T. Tjelflaat (Eds.), Residential care: horizons for the new century (pp. 210-220). Aldershot, UK: Ashgate.

Rogoff, B. (2003). The cultural nature of human development. Oxford, UK: Oxford University Press.

Rogoff, B., Moore, L., Najafi, B., Dexter, A., Correa-Chávez, M., \& Solís, J. (2007). Children's development of cultural repertoires through participation in everyday routines and practices. In J. E. Grusec \& P. D. Hastings (Eds.), Handbook of socialization: Theory and research (pp. 490-515). New York: Guilford Press.

Ruesch, J., \& Bateson, G. (1951). Communication, the social matrix of psychiatry. W. W: Norton \& Company.

Rutter, M. (2000). Children in substitute care, come conceptual implications and research implications. Children \& Youth Services Review, 22(9-10), 685-703. https://doi.org/10.1016/S0190-7409(00)00116-X.

Rutter, M., Colvert, E., Kreppner, J., Beckett C., Castle, J., Groothues, C., Hawkins, A., O’Connor, T.G., Stevens, S.E:, \& Sonuga-Barke, E.J.S. (2007). Early adolescent outcomes for institutionally-deprived and non-deprived adoptees. I: disinhibited attachment. Journal of Child Psychology and Psychiatry, 48(1), 1730. DOI: https://doi.org/10.1111/j.1469-7610.2006.01688.x

Saglietti, M. (2012). Organizzare le case-famiglia. Strumenti e pratiche per le comunità per minori [Organizing group care. Tools and practices for residential care for children]. Rome, IT: Carocci.

Saglietti, M. (2019). 'Inevitable distinctions': The discursive construction of unaccompanied minors' agency in Italian residential care. Language and Dialogue, 9(1), 172-190. https://doi.org/10.1075/ld.00037.sag.

Sairanen, H., Kumpulainen, K., \& Kajamaa, A. (2020). An investigation into children's agency: Children's initatives and practitioners' responses in Finnish early childhood education. Early Child Development and Care, 1-12. https://doi.org/10.1080/03004430.2020.1739030.

Sarangi, S. (2006). Editorial. Advanced in family interaction studies, Text \& Talk, 26(4/5), 403-405. https://doi. org/10.1515/TEXT.2006.015.

Sellers, D. E., Smith, E. G., Izzo, C. V., McCabe, L. A., \& Nunno, M. A. (2020). Child feelings of safety in residential care: The supporting role of adult-child relationships. Residential Treatment for Children \& Youth, 37(2), 136-155. https://doi.org/10.1080/0886571X.2020.1712576.

Sirota, K. G. (2006). Habits of the hearth: Children's bedtime routines as relational work. Text \& Talk, 26(4-5), 493-514. https://doi.org/10.1515/TEXT.2006.020.

Smith, Y. (2020). Can children be safe if their caregivers are not?: Reflections on the "promise" study of workforce issues in a residential treatment center for children. Residential Treatment for Children \& Youth, 37(2), 156-173. https://doi.org/10.1080/0886571X.2019.1704672.

Stern, D. (1977). The first relationship: Infant and mother. Cambridge, MA: Harvard University Press. 
Stivers, T. (2008). Stance, alignment, and affiliation during storytelling: When nodding is a token of affiliation. Research on Language and Social Interaction, 41(1), 31-57. https://doi.org/10.1080/08351810701691123.

Streeck, J., Goodwin, C., \& LeBaron, C. (2011). Embodied interaction: Language and body in the material world. Cambridge, MA: Cambridge University Press.

Swartz, R. (2005). The residential care handbook. Durham, NC: Carolina Academic Press.

Tan, J. (2010). Regulating life in residential care: The unassuming authority of the timetable. Literacy, 44(1), 3742. https://doi.org/10.1111/j.1741-4369.2010.00542.x.

Tannen, D., Kendall, S., \& Gordon, C. (2007). Family talk. Discourse and identity in four American families. Oxford, NY: Oxford University Press.

Tulbert, E., \& Goodwin, M. H. (2011). Choreographies of attention: multimodality in a routine family activity. In J. Streeck, C. Goodwin, \& C. LeBaron (Eds.), Embodied Interaction: Language and Body in the Material World (pp. 79-92). Cambridge, MA: Cambridge University Press.

van Es, C. M., Sleijpen, M., Mooren, T., te Brake, H., Ghebreab, W., \& Boelen, P. A. (2019). Eritrean unaccompanied refugee minors in transition: A focused ethnography of challenges and needs. Residential treatment for Children \& Youth, 36(2), 157-176. https://doi.org/10.1080/0886571X.2018.1548917.

Vygotskij, L. S. (1929). The problem of the cultural development of the child. Journal of Genetic Psychology, $36,415-432$.

Ward, A. (2004). Towards a theory of the everyday: The ordinary and the special in daily living in residential care. Child \& Youth Care Forum, 33(3), 209-225. https://doi.org/10.1023/B:CCAR.0000029686.10310.49.

Ward, A. (2006). Models of 'ordinary' and 'special' daily living: Matching residential care to the mental-health needs of looked after children. Child and Family Social Work, 11(4), 336-346. https://doi.org/10.1111/j. 1365-2206.2006.00423.x.

Wells, G. (1993). Reevaluating the IRF sequence: A proposal for the articulation of theories of activity and discourse for the analysis of teaching and learning in the classroom. Linguistics and Education, 5(1), 1-17. https://doi.org/10.1016/S0898-5898(05)80001-4.

Whittaker, J. K., et al. (2016). Therapeutic residential care for children and youth: A consensus statement of the International Work Group on Therapeutic Residential Care. Residential Treatment for Children \& Youth, 33(2), 89-106. https://doi.org/10.1080/0886571X.2016.1215755.

Zittoun, T. (2006). Transitions. Development through symbolic resources. Charlotte, NC: Information Age Publishing.

Zittoun, T., \& Perret-Clermont, A. (2009). Four social psychological lenses for developmental psychology. European Journal of Psychology of Education, 24(3), 387-403. https://doi.org/10.1007/BF03174768.

Zucchermaglio, C., \& Fasulo, A. (2008). Narratives in the workplace: Facts, fictions, and canonicity. Text and Talk, 28(3), 351-376. https://doi.org/10.1515/TEXT.2008.017.

Zucchermaglio, C., Alby, F., Fatigante, M., \& Saglietti, M. (2013). Fare ricerca situata in Psicologia Sociale [Doing situated research in Social Psychology]. Roma, IT: Carocci.

Publisher's note Springer Nature remains neutral with regard to jurisdictional claims in published maps

Publisher's note Springer Nature remains neutral with regard to jurisdictional claims in published maps and institutional affiliations.

and institutional affiliations.

Marzia Saglietti, Ph.D. Department of Education "G.M. Bertin”, University of Bologna, Bologna, Italy. E-mail address: marzia.saglietti@unibo.it

Current themes of research:

Children in residential care (unaccompanied minors, children and families, etc.). Social interactions in preschools, primary schools and residential care for children. Social interactions in families. Social interactions in health care contexts and in interprofessional care. Children's and adults' literacy.

Most relevant international publications in the field of Psychology of Education:

Saglietti M. (2019). 'Inevitable distinctions'. The discursive construction of unaccompanied minors' agency in Italian residential care. Language \& Dialogue, 9(1):172-190. 
Saglietti M. (2012). Organizzare le case-famiglia. Strumenti ed interazioni nelle comunità per minori. [Organizing children's homes. Tools and interactions in residential care for children]. Roma: Carocci.

Saglietti M., Zucchermaglio C. (2010). Minori stranieri non accompagnati, famiglie d'origine e mandato economico: quale rapporto? [Unaccompanied minors, families and economic mandate: what relationship?], Rivista di Studi Familiari, 10(1), 40-58.

Fatigante, M., Zucchermaglio, C., Fantasia, V. (2020). Shaping the child's participation: How educators socialize children to properly attend activities in kindergarten. Working paper under submission.

Zucchermaglio C., Alby, F. (2014) "It seems that things take care of themselves": routines as resources for the management of busy family life. Mind, Culture and Activity, 21(1): 21-33, DOI: 10.1080/ 10749039.2013.772638

Ferreiro, E., Pontecorvo, C., \& Zucchermaglio, C. (1996). Pizza or Piza? How children interpret the doubling of letters in writing. In C. Pontecorvo, M. Orsolini, B. Burge, \& L. B. Resnick (Eds.), Children's early text construction (p. 145-163). Lawrence Erlbaum Associates, Inc.

Ferreiro, E., Zucchermaglio, C. (1996) Children's use of punctation marks: the case of "quoted speech" In C. Pontecorvo, M. Orsolini, B. Burge, \& L. B. Resnick (Eds.), Children's early text construction (p. 145-163). Lawrence Erlbaum Associates, Inc.

Zucchermaglio, C., Scheuer (1996). Children dictating a story: together is better? In C. Pontecorvo, M. Orsolini, B. Burge, \& L. B. Resnick (Eds.), Children's early text construction (p. 83-98). Lawrence Erlbaum Associates, Inc.

Zucchermaglio, C. (1995), Technology for cooperative learning and working. In Zucchermaglio, C., Bagnara, S., Stucky, S. U. (Eds.), Organizational Learning and technological change (p. 61-74). New York: Springer.

Zucchermaglio, C. (1993). Towards a cognitive ergonomics of educational technology. In Duffy, Thomas M., Lowyck, Joost, Jonassen, David H. (Eds.). Designing Environment for Constructive Learning (pp. 249-260). New York: Springer.

Pontecorvo, C., Zucchermaglio, C. (1991). Computer use in learning about language, European Journal of Psychology of Education, 6(1):15-27

Pontecorvo, C.; Zucchermaglio, C. (1989). From oral to written language; preschool children dictating stories, Journal of Reading Behavior, 21(2):109-126.

Zucchermaglio, C. (1989). Literacy development through social interaction, Dossier de Psychologie, 37.

Pontecorvo C., Zucchermaglio C. (1988). Modes of Differentiation in Children's Writing Construction, European Journal of Psychology of Education, 3(4), pp. 371-384.

Springer Nature remains neutral with regard to jurisdictional claims in published maps and institutional affiliations. 